\title{
Smoking and pulmonary sarcoidosis: effect of cigarette smoking on prevalence, clinical manifestations, alveolitis, and evolution of the disease
}

\author{
DOMINIQUE VALEYRE, PAUL SOLER, CHRISTINE CLERICI, JACQUES PRÉ, \\ JEAN-PAUL BATTESTI, ROBERT GEORGES, ALLAN J HANCE
}

From INSERM Unité 82, Faculté Xavier Bichat, Paris; and Département de Pneumologie, Hôpital Avicenne, Bobigny, France

ABSTRACT Patients with pulmonary sarcoidosis are less likely to smoke than persons of a similar age in the general population. This could be because smoking reduces the likelihood of developing sarcoidosis, or alternatively smoking could reduce the severity of the disease process so that smoking patients are underrepresented among patients with clinically overt disease. To evaluate these possibilities 64 patients with sarcoidosis of recent onset were studied at presentation and after a onछ year follow up period, clinical, functional, radiographic, and bronchoalveolar lavage fluid criteria脑 being used to identify factors that might account for the lower incidence of sarcoidosis in smokers and to determine whether the disease is less severe in smoking patients. Smoking was less common in thes patients with sarcoidosis $(30 \%)$ than in the control subjects $(46 \%)$. The study did not support the conclusion that sarcoidosis is less severe in smokers, as clinical, radiographic, and functiona abnormalities were similar in smokers and non-smokers at initial evaluation and after a one year follow up period. Nevertheless, smoking did influence various indices used to assess disease $\vec{b}$ "activity." Cigarette smoking was associated with a significant increase in the serum angiotensin? converting enzyme activity (SACE), and patients with very high SACE and pulmonary gallium-67? uptake were smokers. Furthermore, more $\mathrm{CD}^{+}$(but not $\mathrm{CD}^{+}$) lymphocytes were recovered by. lavage from smoking than from non-smoking patients, giving a lower CD4 :CD8 ratio in smokers: Fewer alveolar macrophages were recovered by lavage from smokers with sarcoidosis than from normal subjects with a similar smoking history. These findings support the possibility that smokers ${ }_{0}^{\times}$ particularly those with a prominent accumulation of alveolar macrophages in the lower respiratorye. tract, may be less likely to develop sarcoidosis.

\section{Introduction}

Pulmonary sarcoidosis is a granulomatous lung disease in which granuloma formation is preceded by the appearance of an "alveolitis" characterised by increased numbers of $T$ lymphocytes and inflammatory cells. ${ }^{12}$ As this immune and inflammatory response develops in situ within the lung, we may reasonably assume that other factors influencing the number and state of activation of immune and inflammatory cells in the lung might alter the initiation or evolution of the alveolitis.

Cigarette smoking is known to produce various

Address for reprint requests: Dr A J Hance, INSERM U82, Faculté Xavier Bichat, 16 rue Henri Huchard, 75018 Paris, France.

Accepted 14 April 1988 alterations in the number, type, and functional activity of lung immune and inflammatory cells. ${ }^{34} \mathrm{We}$ and others have suggested that the incidence of sarcoidosis. is lower among individuals who smoke than among non-smokers, at least in certain subpopulations of patients. ${ }^{5-11}$ Two explanations could account for this apparent difference: smoking might reduce the likelis hood of developing sarcoidosis, or alternatively i could influence the evolution of the disease so that the signs and symptoms are less severe and therefore smoking patients are underrepresented in series of patients with clinically overt disease.

To evaluate these two possibilities we have studied $\stackrel{\circ}{\circ}$ homogeneous group of patients with sarcoidosis o\& recent onset at presentation and after a one year follow: up period using clinical, functional, radiographic, and bronchoalveolar lavage fluid indices, to identifys 
factors that might account for a lower prevalence of sarcoidosis among cigarette smokers and to determine whether the clinical course of sarcoidosis is less severe in smokers than in non-smokers.

\section{Methods}

STUDY POPULATIONS

Patients with sarcoidosis

All patients with pulmonary sarcoidosis evaluated at Hôpital Avicenne from February 1984 to August 1986 were considered for this study. The diagnosis of pulmonary sarcoidosis was established according to previously described criteria, ${ }^{12}$ which included: (1) a compatible clinical picture; (2) presence of noncaseating granulomas in biopsy samples of lung, bronchus, mediastinal nodes, or the site of a KveimSiltzbach reaction: (3) absence of mycobacterial or fungal infections: and (4) absence of exposure to agents known to produce granulomatous disease. For the purpose of this study the duration of disease was regarded as the interval between evaluation and the last normal chest radiograph or since the onset of erythema nodosum.

Among the 133 patients identified, 92 were nonsmokers and 39 were current smokers; only two patients were former smokers and these individuals were excluded from the study. There was no significant difference in mean (SD) age between the two groups (non-smokers 36 (11), smokers 32 (12) years; $p>0 \cdot 2$ ), although men were more likely to smoke (nonsmokers, 30 men/62 women; smokers, 24 men/15 women; $\mathrm{p}<0.01$ by $\chi^{2}$ analysis). Mean cigarette consumption by smoking patients was 10 (SD 8) cigarettes a day. Twenty two patients smoked under 10 cigarettes a day, 11 patients $11-20 / \mathrm{d}$, and six patients over $20 /$ d.

For evaluation of the influence of cigarette smoking on pulmonary function, indices of disease activity, and evolution, three groups of patients were excluded to restrict the study to a homogeneous population. Patients were excluded for the following reasons: (1) Patients who had received corticosteroid treatment before their initial evaluation by us $(n=27,15$ non-smokers); (2) patients with disease of over two years' duration ( $\mathrm{n}=20,14$ non-smokers); (3) patients with disease of less than two months' duration $(n=20)$; all of the latter patients presented with erythema nodosum and were excluded because patients with erythema nodosum evaluated less than two months after the onset of the disease have clinical and lavage fluid findings that are significantly different from those observed in patients (with or without erythema nodosum) evaluated after longer intervals from the onset of the disease. ${ }^{13}$ Furthermore, patients with erythema nodosum are predominantly female (17

women and three men in this series) and therefore less likely to smoke (18 non-smokers and two smokers). The inclusion of such patients would therefore create a bias as differences resulting only from the early evaluation of these patients would be represented disproportionately in the non-smoking group. The age, sex, and smoking habits of the remaining 64 patients were not significantly different from those of the total study population.

\section{CONTROL SUBJECTS}

For comparison of tobacco consumption between patients with sarcoidosis and the general population, we used results obtained by a survey conducted by the Société Brule Ville Associés and sponsored by the Comité Français d'Education pour la Santé. ${ }^{14}$ The survey sample was representative of the population of France in terms of age, sex, and socioeconomic status. For our study we used only those responses given by people aged 25-49 years.

For comparison of the results of bronchoalveolar lavage, 36 normal volunteers served as control subjects ( 25 men, 11 women). Fifteen were non-smokers (mean age 40 (SD 13) years) and 21 smoked cigarettes (age 35 (12) years). Mean cigarette consumption by smoking control subjects was 28 (18) cigarettes a day. Four subjects smoked less than $10 / \mathrm{d}$, eight $11-20 / \mathrm{d}$, and nine over $20 / d$.

\section{BRONCHOALVEOLAR LAVAGE}

All patients with sarcoidosis underwent bronchoalveolar lavage as part of a diagnostic evaluation. Patients and normal volunteers gave informed consent before the procedure. Lavage was performed as previously described, ${ }^{12}$ five aliquots $(50 \mathrm{ml}$ each) of sterile saline being used. The total number of cells recovered $/ \mathrm{ml}$ lavage fluid was determined by counting cells present in an aliquot of the resuspended original lavage fluid. Cytocentrifuge preparations were made from uncentrifuged lavage fluid and stained with MayGrünwald-Giemsa stain, and a differential cell count was performed by examining at least 1000 cells. Lavage fluid was centrifuged $(600 \mathrm{~g}$ for 10 minutes) and supernatant fluid was stored at $-20^{\circ} \mathrm{C}$. Cells were resuspended at a concentration of $10^{7}$ cells $/ \mathrm{ml}$ in RPMI-1640 medium containing $25 \mathrm{mM}$ Hepes.

The surface phenotype of lymphocytes recovered by lavage was evaluated by indirect immunofluorescence microscopy as previously described, ${ }^{15}$ with monoclonal antibodies recognising CD4 (OKT4 plus OKT4A, Ortho Diagnostics, Raritan NJ) and CD8 (OKT8, Ortho) determinants.

Albumin and immunoglobulin $\mathrm{G}$ (IgG) in lavage fluid were measured by immunoprecipitation with a laser nephelometer (Behring Diagnostics, Paris, France) without prior concentration of the supernatant. ${ }^{12}$ 
MEASUREMENT OF SERUM ANGIOTENSIN CONVERTING ENZYME ACTIVITY, IgG, AND ALBUMIN

Serum angiotensin converting enzyme (SACE) activity was assayed with hippuryl histidine leucine as substrate ${ }^{16}$ the normal range $(40.7 \pm 20.4$ units $)$ represents the mean concentration with 2 standard deviations in serum from an independent group of 50 normal volunteers. ${ }^{16}$ Serum IgG and albumin were measured by laser nephelometry, as described above for bronchoalveolar lavage fluid.

EVALUATION OF FUNCTIONAL INDICES, PULMONARY GALLIUM-67 UPTAKE, AND

RADIOGRAPHIC ABNORMALITIES

Vital capacity and FEV, were measured by spirometry (Godart water sealed spirometer) and functional residual capacity by multiple breath helium dilution. Carbon monoxide transfer factor (TLCO) was measured by the single breath method ${ }^{17}$ and scaled for age and height. The results were compared with previously published standards. ${ }^{18} 19$

The pulmonary gallium -67 index was determined by a modification of the method of Line et al. ${ }^{2021}$ The upper limit of normal ( 23 units) represents the mean + 2 SD for tests performed on 11 normal volunteers. Gallium scans were performed on 31 out of 66 patients. The age, sex, and smoking history of patients evaluated by gallium scans were not significantly different from those of the total study population. Chest radiographs were typed according to the criteria of Siltzbach. ${ }^{22}$

\section{STATISTICAL METHODS}

All data are presented as means with standard deviations in parentheses. One way analysis of variance was used to obtain probability values for comparisons of measurements between groups. All significant differences were confirmed by the non-parametric Kruskall-Wallis method. Paired $t$ tests were used for within group comparisons. The $\chi^{2}$ test was used for data on groups of patients.
Valeyre, Soler, Clerici, Pré, Battesti, Georges, Hance
Results

TOBACCO CONSUMPTION

The patients with sarcoidosis were less likely to smoke? $(30 \%)$ than people of a similar age in the normal population $(46 \%) p<0.05)$. When men and women $\frac{5}{\sqrt{0}}$ with sarcoidosis were considered separately, the $\propto$ percentage of smokers was less in both groups than that observed in the corresponding normal popula- $\vec{\circ}$ tion, although the difference was significant at the $\mathrm{p}<0.05$ level only for women, (patients $v$ control $\vec{\omega}$ subjects: women $19 \% v 35 \%$; $<0.01$; and men $44 \%$ \% $v 57 \% ; 0.1>\mathrm{p}>0.05)$. The leval of tobacco consum- $x$ ption by smoking patients with sarcoidosis was not $\frac{\omega}{\omega}$ significantly different from that of smokers in the $-v$ general population $(p>0.2)$, although most patients $\mathrm{c}$ and controls who were smokers smoked less than $20 \vec{\circ}$ cigarettes/day.

RELATION OF CIGARETTE SMOKING TO INDICES OF DISEASE ACTIVITY AND SEVERITY AT INITIAL EVALUATION

Chest radiograph

There was no difference in the proportion of non- smoking and smoking patients with hilar adenopathy alone (type 1: non-smokers 29/45, smokers 12/19; p > 0.2 ) or pulmonary infiltration with or without hilar lymph adenopathy (types 2 and 3: non-smokers $\mathbb{D}$ $16 / 45$, smokers $7 / 19 ; \mathrm{p}>0 \cdot 2$ ).

\section{Pulmonary function}

The patients with sarcoidosis as a group had a mild reduction in vital capacity, residual volume, and diffusing capacity (table 1). No significant differences were observed between non-smokers and smokers for any index, and the proportion of patients with $a$ greater than $20 \%$ decrease compared to predicted 3 . values was similar for the two groups (table 1).

\section{Cells recovered by bronchoalveolar lavage}

Among the patients with sarcoidosis a significantly greater number of alveolar macrophages was

Table 1 Pulmonary function tests in patients with sarcoidosis as a function of smoking history

\begin{tabular}{|c|c|c|c|c|c|}
\hline \multirow[b]{2}{*}{ Study group } & \multicolumn{5}{|c|}{ Pulmonary function (mean (SD)) } \\
\hline & $T L C$ & $V C$ & $\boldsymbol{R} V$ & $F E V_{1} / V C$ & $T L C O$ \\
\hline $\begin{array}{l}\text { NON-SMOKERS }(n=42) \\
\% \text { predicted } \\
\text { No of patients with }>20 \% \text { decrease from predicted }\end{array}$ & $\begin{array}{l}88(13) \\
12 / 42\end{array}$ & $\begin{array}{l}94(18) \\
7 / 42\end{array}$ & $\begin{array}{l}74(17) \\
26 / 42\end{array}$ & $\begin{array}{l}97(8) \\
1 / 42\end{array}$ & $\begin{array}{l}74(17) \\
26 / 39\end{array}$ \\
\hline $\begin{array}{l}\text { SMOKERS }(n=16) \\
\% \text { predicted } \\
\text { No of patients with }>20 \% \text { decrease from predicted }\end{array}$ & $\begin{array}{l}88(17) \\
7 / 16\end{array}$ & $\begin{array}{l}89(19) \\
6 / 16\end{array}$ & $\begin{array}{l}83(24) \\
10 / 16\end{array}$ & $\begin{array}{l}94(9) \\
2 / 16\end{array}$ & $\begin{array}{c}74(14) \\
9 / 15\end{array}$ \\
\hline
\end{tabular}

TLC - Total lung capacity; VC_-vital capacity; RV—residual volume; FEV monoxide transfer factor. 
Table 2 Numbers and types of cells recovered by lavage from patients with sarcoidosis of recent origin and normal volunteers as a function of smoking history (means with standard deviations in parentheses) $§$

\begin{tabular}{|c|c|c|c|c|c|c|c|}
\hline \multirow[b]{2}{*}{ Study group } & \multirow[b]{2}{*}{$n$} & \multicolumn{6}{|c|}{ Cells recovered by lavage } \\
\hline & & Total cells & Macrophages & Lymphocytes & Neutrophils & Eosinophils & Mast cells \\
\hline $\begin{array}{l}\text { SARCOIDOSIS } \\
\text { Non-smokers }\end{array}$ & 45 & & & & & & \\
\hline $\begin{array}{l}\text { Cells } \times 10^{3} / \mathrm{ml} \\
\% \\
\text { Smokers }\end{array}$ & 19 & $280(13)+\dagger$ & $\begin{array}{l}160(84) \\
59(17)+\dagger\end{array}$ & $\begin{array}{c}115(79)+++ \\
39(17)+++\end{array}$ & $\begin{array}{l}4 \cdot 0(5 \cdot 3) \\
1 \cdot 4(1 \cdot 3)\end{array}$ & $\begin{array}{l}1 \cdot 7(2.8) \\
0.6(0.9)\end{array}$ & $\begin{array}{l}0.70(0.95) \dagger \\
0.25(0.31)+\dagger\end{array}$ \\
\hline$\underset{\%}{\text { Cells }} \times 10^{3} / \mathrm{ml}$ & 19 & $394(184)^{*} \dagger$ & $\begin{array}{r}269(152)+\dagger \\
68(14)++\dagger\end{array}$ & $\begin{array}{l}115(69)+\dagger \\
30(14)^{*}++\dagger\end{array}$ & $\begin{array}{l}5 \cdot 6(5 \cdot 3) \dagger \dagger \\
1 \cdot 3(0 \cdot 8) \dagger\end{array}$ & $\begin{array}{l}2.7(3.6)^{+\dagger} \\
0.6(0.8)\end{array}$ & $\begin{array}{l}1.00(1.60) \\
0.24(0.38)\end{array}$ \\
\hline $\begin{array}{l}\text { NORMAL SUBJECTS } \\
\text { Non-smokers }\end{array}$ & 15 & & & & & & \\
\hline $\begin{array}{l}\text { Cells } \times 10^{3} / \mathrm{ml} \\
\% \\
\text { Smokers }\end{array}$ & 8 & $155(68)$ & $\begin{array}{c}136(61) \\
88(5)\end{array}$ & $\begin{array}{l}16(9) \\
11(5)\end{array}$ & $\begin{array}{l}2.0(1.9) \\
1 \cdot 1(0.8)\end{array}$ & $\begin{array}{l}0.4(0.7) \\
0.3(0.5)\end{array}$ & $\begin{array}{l}0.01(0.05) \\
0.02(0.06)\end{array}$ \\
\hline $\begin{array}{l}\text { Smokers } \\
\text { Cells } \times 10^{3} / \mathrm{ml} \\
\end{array}$ & 8 & $535(327)^{* * *}$ & $\begin{array}{l}488(304)^{* * * *} \\
90(3)\end{array}$ & $\begin{array}{r}22(8) \\
6(4)\end{array}$ & $\begin{array}{l}13.4(11.4)^{* * * *} \\
2.5(2.3)\end{array}$ & $\begin{array}{l}12.0(21.3)^{* * * *} \\
1.3(1.9)\end{array}$ & $\begin{array}{l}0.30(0.50) \\
0.07(0.15)\end{array}$ \\
\hline
\end{tabular}

$\S$ Statistical comparisons: non-smokers $v$ smokers*; sarcoidosis patients $v$ normal subjects with a similar smoking history†. One, two, and three symbols indicate respectively $\mathrm{p}<0.05, \mathrm{p}<0.01$, and $\mathrm{p}<0.001$.

recovered by lavage from smoking patients than from non-smoking patients. Among smokers the number of macrophages obtained from patients with sarcoidosis was less than that recovered from control subjects (table 2; $\mathrm{p}<0.001$ for control $v$ sarcoidosis group).

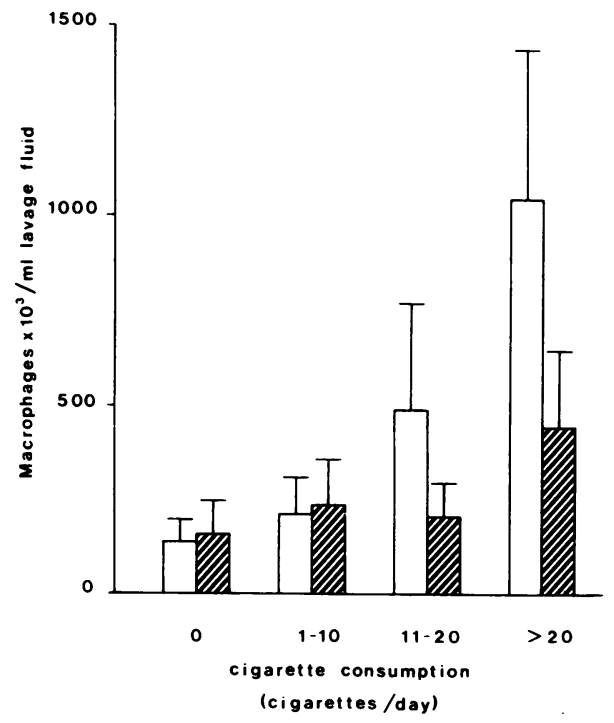

Fig 1 Number of alveolar macrophages recovered by bronchoalveolar lavage from normal subjects and patients with sarcoidosis of recent origin as a function of cigarette consumption. Results are expressed as means with standard deviations for normal volunteers (open bars) and patients with sarcoidosis (hatched bars). The number of alveolar macrophages recovered from patients with sarcoidosis smoking 11-20 and over 20 cigarettes/day was significantly lower than that of normal subjects with a similar smoking history ( $p<0.001$ for both comparisons).
The reduced number of alveolar macrophages recovered from sarcoid smokers compared with control smokers was not entirely explained by differences in tobacco consumption. When control subjects were subdivided according to cigarette consumption the number of macrophages recovered increased progressively as a function of cigarette consumption (fig 1). In contrast, only those patients with sarcoidosis who smoked over 20 cigarettes a day had more alveolar macrophages than non-smokers with sarcoidosis, and the total number of macrophages recovered from these patients with a heavy smoking history was significantly less than that of controls with a similar smoking history (fig $1 ; p<0.001$ ).

The numbers of lymphocytes recovered $/ \mathrm{ml}$ lavage fluid in the patients with sarcoidosis was not significantly different in non-smokers and smokers (table 2), nor did smoking modify the total number of $\mathrm{CD}^{+} \mathrm{T}$ lymphocytes recovered by lavage (table 3 ). Smoking, however, was associated with a twofold increase in the number of $\mathrm{CD}^{+} \mathrm{T}$-lymphocytes recovered (table 3 ) and as a consequence the CD4 : CD8 ratio was significantly lower among smokers than non-smokers with sarcoidosis.

In the patients with sarcoidosis there were no significant differences between smokers and nonsmokers in the numbers of neutrophils, eosinophils, or mast cells recovered by lavage (table 2 ). The smokers had significantly fewer neutrophils in lavage fluid than the control smokers, but this may reflect the fact that cigarette consumption by the smokers with sarcoidosis was less than that of our control smoking population $(\mathrm{p}<0.001)$.

\section{IgG content in lavage fluid and serum}

The patients with sarcoidosis, both non-smokers and 
Table 3 Surface phenotype of $T$ lymphocytes recovered by lavage from patients with sarcoidosis of recent origin and normal volunteers as a function of smoking history (means with standard deviations in parentheses) §

\begin{tabular}{|c|c|c|c|c|c|c|}
\hline \multirow[b]{3}{*}{ Study group } & \multirow[b]{3}{*}{$n$} & \multicolumn{4}{|c|}{ Tlymphocyte phenotype } & \multirow[b]{3}{*}{ CD4:CD8 ratio } \\
\hline & & \multicolumn{2}{|c|}{ CD4 $4^{+}$lymphocytes } & \multicolumn{2}{|c|}{ CD8 $8^{+}$lymphocytes } & \\
\hline & & Cells $\times 10^{3} / \mathrm{ml}$ & $\%$ & Cells $\times 10^{3} / \mathrm{ml}$ & $\%$ & \\
\hline $\begin{array}{l}\text { SARCOIDOSIS } \\
\text { Non-smokers } \\
\text { Smokers }\end{array}$ & $\begin{array}{l}45 \\
19\end{array}$ & $\begin{array}{l}93(66)+\dagger+ \\
79(53)^{+\dagger}\end{array}$ & $\begin{array}{l}78.9(14 \cdot 0)++\dagger \\
65.8(15 \cdot 7)+\dagger^{* *}\end{array}$ & $\begin{array}{l}15(12.5)+\dagger \\
31(19.4)+\dagger+* * *\end{array}$ & $\begin{array}{l}15 \cdot 4(10)+\dagger \dagger \\
30 \cdot 1(14.8)+\dagger+* * *\end{array}$ & $\begin{array}{l}8 \cdot 1(5 \cdot 9)+\dagger \dagger \\
3 \cdot 2(2 \cdot 7))^{* *}\end{array}$ \\
\hline $\begin{array}{l}\text { NORMAL SUBJECTS } \\
\text { Non-smokers } \\
\text { Smokers }\end{array}$ & $\begin{array}{r}15 \\
8\end{array}$ & $\begin{array}{l}9.5(5.8) \\
9.5(2.5)\end{array}$ & $\begin{array}{l}58 \cdot 7(11 \cdot 1) \\
44 \cdot 4(12 \cdot 1)^{* *}\end{array}$ & $\begin{array}{c}5 \cdot 1(2 \cdot 9) \\
12 \cdot 2(4 \cdot 6)^{* * *}\end{array}$ & $\begin{array}{l}32 \cdot 0(6 \cdot 1) \\
54 \cdot 0(7 \cdot 7)^{* * *}\end{array}$ & $\begin{array}{l}1.9(0.5) \\
0.8(0.3)^{* * *}\end{array}$ \\
\hline
\end{tabular}

$\S$ Statistical comparisons: non-smokers $v$ smokers*; sarcoidosis patients $v$ normal subjects with a similar smoking history†. One, two, and $\vec{\omega}$ three symbols indicate respectively $\mathrm{p}<0.05, \mathrm{p}<0.01$, and $\mathrm{p}<0.001$.

smokers, had higher IgG concentrations in the fluid recovered by bronchoalveolar lavage than the control non-smokers (table 4). As the albumin recovered $/ \mathrm{ml}$ lavage fluid was similar for control subjects and patients, regardless of their tobacco consumption, the IgG:albumin ratio was higher in patients than in control subjects but similar for non-smoking and smoking patients.

The concentration of IgG in serum was similar for smoking and non-smoking patients with sarcoidosis. When they were considered as a group, the concentration of serum IgG was similar in patients with sarcoidosis and controls. In the sarcoid group, however, 10 of 30 non-smoking patients and two of 12 smoking patients had clearly increased serum immunoglobulin concentrations ( $p>0.2$ for smokers $v$ non-smokers with sarcoidosis by $\chi^{2}$ analysis).

\section{Pulmonary gallium uptake}

No significant difference in ${ }^{67} \mathrm{Ga}$ accumulation was observed between non-smoking and smoking patients (fig $2 a$ ). The two patients with very high ${ }^{67} \mathrm{Ga}$ indices were both heavy smokers ( $>20$ cigarettes/day).

\section{Serum angiotensin converting enzyme activity}

In the patients with sarcoidosis SACE activity was significantly higher in smokers than non-smokers $\frac{\vec{\sigma}}{2}$ (SACE: non-smokers 72.4 (32.9) units; smokers 99.2음 (66.3) units; $p<0.05$ ), although considerable overlap was observed between the groups (figure $2 b$ ). $\subseteq$ Individual smokers were also more likely to have increased SACE than non-smokers (SACE $>50$ units: $\vec{\oplus}$ non-smokers 36/48; smokers 19/20; p < 0.001). The $\infty$ two patients with very high SACE activity had both smoked $\mathbf{2 0}$ or more cigarettes a day. No correlation was observed, however, between the number of alveolar macrophages recovered by lavage from smokers with sarcoidosis and SACE activity in these $\frac{\mathrm{D}}{\mathrm{O}}$ individuals $(\mathrm{p}>0 \cdot 2)$.

\section{RELATION OF CIGARETTE SMOKING TO THE EVOLUTION OF SARCOIDOSIS}

Treatment with corticosteroids

Information on the clinical course during a follow up period of one year was available for $46(72 \%)$ of the 64 patients with sarcoidosis initially evaluated. There was no significant difference in the number of non- 3 smoking patients $(10 / 33)$ and smoking patients $(5 / 13)$ who received corticosteroids $(p>0 \cdot 2)$. The primary indication for steroid treatment in both groups was $\bigcirc$ usually the presence of extrapulmonary sarcoidosis or severe systemic symptoms $(9 / 10$ non-smokers and $4 / 5$ 음

Table 4 Immunoglobulin $G$ and albumin concentrations in serum and lavage fluid from patients with sarcoidosis and controls as a function of smoking history (means with standard deviations in parentheses) $\S$

\begin{tabular}{|c|c|c|c|c|c|c|c|c|}
\hline \multirow[b]{2}{*}{ Study group } & \multicolumn{4}{|c|}{ Serum } & \multicolumn{4}{|c|}{ Lavage fluid } \\
\hline & $n$ & $\begin{array}{l}\lg G \\
(\mathrm{~g} / \mathrm{l} / 00 \mathrm{ml})\end{array}$ & $\begin{array}{l}\text { Albumin } \\
(\mathrm{g} / 100 \mathrm{ml})\end{array}$ & $\operatorname{Ig} G / A l b$ & $n$ & $\begin{array}{l}\text { IgG } \\
(\mu g / m l)\end{array}$ & $\begin{array}{l}\text { Albumin } \\
(\mu \mathrm{g} / \mathrm{ml})\end{array}$ & $I g G / A l b$ \\
\hline $\begin{array}{l}\text { SARCOIDOSIS } \\
\text { Non-smokers } \\
\text { Smokers }\end{array}$ & $\begin{array}{l}33 \\
13\end{array}$ & $\begin{array}{l}1.58(0.5) \\
1.44(0.5)\end{array}$ & $\begin{array}{l}3.8(0.4) \dagger \\
3.7(0.6) \dagger\end{array}$ & $\begin{array}{l}0.42(0.15) \\
0.39(0.15)\end{array}$ & $\begin{array}{l}38 \\
15\end{array}$ & $\begin{array}{l}35.5(25 \cdot 3) \dagger+\dagger \\
31.5(15 \cdot 9) \dagger\end{array}$ & $\begin{array}{l}82.3(62.8) \\
80.7(22.9)\end{array}$ & $\begin{array}{l}0.49(0.25)+\dagger \dagger \\
0.40(0.17) \dagger\end{array}$ \\
\hline $\begin{array}{l}\text { NORMAL SUBJECTS } \\
\text { Non-smokers } \\
\text { Smokers }\end{array}$ & $\begin{array}{l}8 \\
6\end{array}$ & $\begin{array}{l}1.33(0 \cdot 20) \\
1.30(0 \cdot 20)\end{array}$ & $\begin{array}{l}4.2(0.03) \\
4.2(0.04)\end{array}$ & $\begin{array}{l}0.34(0.09) \\
0.33(0.10)\end{array}$ & $\begin{array}{l}8 \\
6\end{array}$ & $\begin{array}{r}7 \cdot 6(2) \\
11 \cdot 1(3)\end{array}$ & $\begin{array}{l}61.6(23.5) \\
81.8(20.8)\end{array}$ & $\begin{array}{l}0.14(0.08) \\
0.17(0.05)\end{array}$ \\
\hline
\end{tabular}

§Statistical comparisons: non-smokers $v$ smokers*; sarcoidosis patients $v$ normal subjects with a similar smoking history $\dagger$. One, two, and three symbols indicate respectively $\mathrm{p}<0.05, \mathrm{p}<0.01, \mathrm{p}<0.001$. 


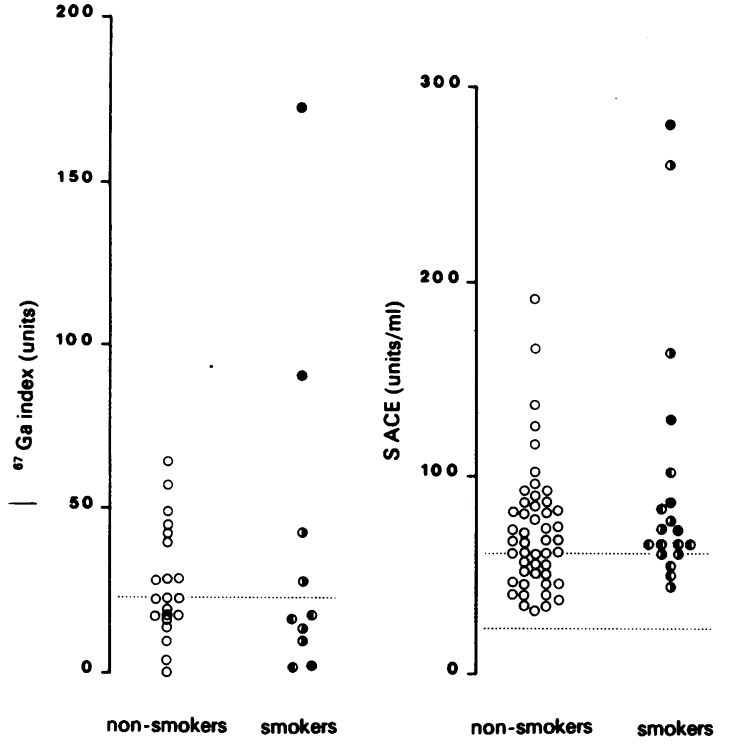

Fig 2 Pulmonary gallium-67 index (left panel) and serum angiotensin converting enzyme activity (SACE, right panel) in patients with sarcoidosis. Results are shown for patients who were non-smokers (O) and patients who smoked $<10$ cigarettes/day (0), 11-20 cigarettes/day (0), and $>20$ cigarettes/day (๑). For the ${ }^{67} \mathrm{Ga}$ index the dotted line represents the upper normal limit (mean $+2 S D$ ); for $S A C E$ the dotted lines indicate the mean and $2 S D$ for normal controls.

smokers). One patient in each group received corticosteroids solely because of dyspnoea, although a further three of the nine non-smokers and three of the four smokers treated with corticosteroids had dyspnoea on exertion.
Table 5 Evolution of radiographic abnormalities in patients with sarcoidosis over a one year follow up period

\begin{tabular}{llllll}
\hline $\begin{array}{l}\text { Study } \\
\text { group }\end{array}$ & $n$ & $\begin{array}{l}\text { Complete } \\
\text { resolution }\end{array}$ & $\begin{array}{l}\text { Partial } \\
\text { resolution }\end{array}$ & Stable & $\begin{array}{l}\text { Deterio- } \\
\text { rated }\end{array}$ \\
\hline NON-SMOKERS & 33 & & & & \\
Untreated & 23 & 17 & 0 & 6 & 0 \\
Treated & 10 & 7 & 0 & 3 & 0 \\
SMOKERS & 13 & & & & \\
Untreated & 8 & 6 & 0 & 1 & 1 \\
Treated & 5 & 3 & 2 & 0 & 0 \\
\hline
\end{tabular}

Radiographic findings

Most patients had complete or partial resolution of radiographic abnormalities after 12 months of follow up (table 5). The proportion of patients with complete resolution, partial resolution, stability, or deterioration of radiographic abnormalities did not differ between smokers and non-smokers.

\section{Lung function}

The non-smoking patients had only slight changes in pulmonary function during the follow up period of $12 \cdot 2(4.5)$ months (table 6), though vital capacity and TLCo showed significant increases. Changes in indices of pulmonary function in smokers did not differ significantly from those observed in non-smokers, even though the average length of follow up was somewhat longer (13.6 (5.6) months). Furthermore, the proportion of patients who showed a greater than $20 \%$ decrease in any given index of pulmonary function was similar for non-smokers and smokers (table 6).

\section{Discussion}

SMOKING AND THE PREVALENCE OF SARCOIDOSIS In our study patients with pulmonary sarcoidosis were

Table 6 Evolution of functional measurements in patients with sarcoidosis over a one year follow up period (mean differences in \% predicted values between last and first test, with standard deviations in parentheses)

\begin{tabular}{|c|c|c|c|c|c|c|}
\hline \multirow[b]{2}{*}{ Study group } & \multirow[b]{2}{*}{$n$} & \multicolumn{5}{|c|}{ Pulmonary function } \\
\hline & & $V C$ & $\boldsymbol{R} V$ & $T L C$ & $F E V, / V C$ & Thco \\
\hline \multirow{2}{*}{$\begin{array}{l}\text { NON-SMOKERS } \\
\Delta \% \text { predicted } \\
\text { Number who } \\
\text { decreased } 20 \% \\
\text { increased } 20 \%\end{array}$} & 12 & $+5.7(9.0)^{*}$ & $-7 \cdot 2(18 \cdot 6)$ & $+1.5(7.9)$ & $+2 \cdot 8(8)$ & $+7 \cdot 8(2 \cdot 3)^{*}$ \\
\hline & & $\begin{array}{l}0 \\
2\end{array}$ & $\begin{array}{l}4 \\
0\end{array}$ & $\begin{array}{l}0 \\
1\end{array}$ & $\begin{array}{l}0 \\
0\end{array}$ & $\begin{array}{l}\mathbf{0} \\
\mathbf{3}\end{array}$ \\
\hline \multirow{2}{*}{$\begin{array}{l}\text { SMOKERS } \\
\Delta \% \text { predicted } \\
\text { Number who } \\
\text { decreased } 20 \% \\
\text { increased } 20 \%\end{array}$} & 7 & $+6.6(12 \cdot 7)$ & $+3.4(21.6)$ & $+5 \cdot 3(12 \cdot 8)$ & $+3.7(10.8)$ & $+4 \cdot 6(11 \cdot 6)$ \\
\hline & & $\begin{array}{l}0 \\
2\end{array}$ & $\begin{array}{l}1 \\
2\end{array}$ & $\begin{array}{l}0 \\
2\end{array}$ & $\begin{array}{l}0 \\
1\end{array}$ & $\begin{array}{l}1 \\
1\end{array}$ \\
\hline
\end{tabular}

* $p<0.05$ for comparisons of last and first test results (paired $t$ test).

VC-vital capacity; RV-residual volume; TLC-total lung capacity; FEV, -one second expiratory volume; TLCo-carbon monoxide transfer factor. 
less likely to smoke than people of a similar age in the general population. The failure to find a significant difference in cigarette consumption between men with sarcoidosis and men in the general population reflects, at least in part, the small number of patients evaluated. For example, when the results of the present study (131 patients) are combined with those from a previous study by our group ( 130 different patients), ${ }^{9}$ both men and women with sarcoidosis were found to be less likely to smoke than the corresponding groups in the normal population (men: $p<0.02$; women: $p<0.001$ ), although the differences for men were not significant for either group when these were considered separately. Only patients with overt pulmonary manifestations, however, were studied and the effect of cigarette smoking, if any, on the incidence of extrathoracic sarcoidosis is unknown.

This study was not a case-control study and potential confounding factors such as socioeconomic status and race were not controlled. Our results, however, are concordant with those of several previous studies $^{5-11}$ suggesting that the incidence of sarcoidosis is higher in non-smokers than smokers. Nevertheless, not all studies have shown clearly that smoking reduces the incidence of sarcoidosis, ${ }^{23}{ }^{24}$ and further studies will be required to explain the differing results so far presented.

\section{THE EFFECT OF CIGARETTE SMOKING ON THE \\ SEVERITY OF SARCOIDOSIS}

Our findings do not support the conclusion that the apparent lower incidence of sarcoidosis observed in smokers resulted from the fact that the disease is less severe in these patients. No significant differences were found between smokers and non-smokers in the comparisons of radiographic and functional indices at initial evaluation, and follow up of the two groups did not disclose differences in clinical symptoms, the proportion of patients requiring corticosteroid treatment, or subsequent changes in the results of functional tests or chest radiographs. Although our study did not show major differences in the evolution of lung function in smoking and non-smoking patients studied over one year, we would emphasise that smoking may influence the long term evolution of the disease. For example, Dutton et $a^{25}$ have shown that residual volume is higher in smokers than nonsmokers with chronic sarcoidosis, and we have confirmed this finding in a small group of patients with sarcoidosis of more than three years' duration ( $\mathrm{R}$ Georges, unpublished results).

Nevertheless, cigarette consumption did modify some, though not all, indices used in assessing the "activity" of sarcoidosis. Cigarette smoking was associated with a significant increase in SACE activity in sarcoid patients, and all patients with very high
Valeyre, Soler, Clerici, Pré, Battesti, Georges, Hance $\overline{\bar{จ}}$ SACE activity and ${ }^{67} \mathrm{Ga}$ accumulation smoked 20 or $\stackrel{0}{x}$ more cigarettes a day. Gallium uptake ${ }^{26}$ but not SACE $\vec{\Rightarrow}$ activity ${ }^{26-28}$ have been reported to be higher in smokers $\stackrel{6}{?}$ than in non-smokers with sarcoidosis. Both the release? of angiotensin converting enzyme and ${ }^{67} \mathrm{Ga}$ uptake are $\frac{\bar{\sigma}}{\bar{D}}$ thought to represent, at least in part, alveolar macro- $\frac{\widehat{\sigma}}{\sigma}$ phage activity ${ }^{2829}$ and presumably relate both to the $\stackrel{\mathbb{2}}{\circ}$ number of alveolar macrophages present and their क state of activation. Cigarette smoking alone, which $\vec{\circ}$ increases the number of alveolar macrophages con- siderably, results in only a modest increase in ${ }^{67} \mathrm{Ga} \vec{\omega}$ uptake and no significant increase in SACE activity. ${ }^{283031}$ Furthermore, we observed no correla- $\vec{x}$ tion between the number of alveolar macrophages $\hat{\omega}$ recovered by lavage and these two indices. These $v$ findings suggest that the state of activation of alveolar $\vec{T}$ macrophages is the predominant factor determining $\sigma$ the level of these indices. Nevertheless, the increased $\frac{}{5}$ number of alveolar macrophages that results from $\vec{c}$ smoking in combination with appropriate activation signals (present in some patients with sarcoidosis) may explain the very high ${ }^{67} \mathrm{Ga}$ uptake and SACE activity ${ }_{\infty}^{\circ}$ seen in some, but not all, patients with sarcoidosis who? smoked.

Smoking was also associated with a twofold increase in $\mathrm{CD} 8^{+} \mathrm{T}$ lymphocytes recovered by lavage from patients with sarcoidosis. Similarly, twice as many $\mathrm{CD}^{+} \mathrm{T}$ lymphocytes were observed in smoking $\frac{\mathbb{Q}}{\mathscr{Q}}$ as in non-smoking controls, as reported previously ${ }^{32} \overrightarrow{\vec{F}}$ As smoking did not affect the recovery of $\mathrm{CD}^{+} \mathrm{T}$ 을 lymphocytes, the CD4 : CD8 ratio was significantly? lower in smoking than in non-smoking patients, though it was clearly abnormal in almost all patients who smoked.

In this study, like some ${ }^{93}$ but not all previous studies, ${ }^{34}$ the number of alveolar macrophages $\frac{0}{0}$ recovered from smoking patients with sarcoidosis was much less than the number recovered from controlo subjects with a similar smoking history. This finding is consistent with the possibility that smokers whoo develop a large increase in the number of alveolar $\supset$ macrophages in the lower respiratory tract are을 unlikely to develop pulmonary sarcoidosis, and might explain in part the lower incidence of sarcoidosis in . smokers. In this context, the alveolitis of sarcoidosis is $\tilde{O}$ dependent on the proliferation of $T$ lymphocytes $N$ within the lung parenchyma, ${ }^{135}$ and most previouso studies have shown that "excessive" numbers of alveolar macrophages inhibit $T$ lymphocyte proliferation..$^{36-38}$

Cigarette smoking is recognised not only as 0 increasing the number of alveolar macrophages in the lung but also as influencing their functional activity. As changes in the number and activity of alveolar苑 macrophages may be associated with each other, our results do not exclude the possibility that changes in 
functional activity of these cells induced by cigarette smoking may be important in reducing the likelihood of developing sarcoidosis. For example, some previous studies ${ }^{3839}$ (though not others ${ }^{4041}$ ) indicate that alveolar macrophages from smokers have less accessory cell activity than equal numbers of alveolar macrophages from non-smokers.

Alternatively, the smaller number of alveolar macrophages in smokers with sarcoidosis than in smoking control subjects may be the result of the disease process. For example, sarcoidosis can have an important impact on the phenotype of alveolar macrophages recovered by lavage,$^{42}$ and the development of sarcoidosis could alter the distribution of alveolar macrophages within the lung in such a way that fewer cells are recovered by lavage. The fact, however, that just as many alveolar macrophages were recovered from non-smoking patients with sarcoidosis as from non-smoking controls does not support this hypothesis.

In conclusion, our study supports the idea that smoking reduces the incidence of sarcoidosis. Furthermore, smoking modifies the results of various tests that have been used in the evaluation of these patients, and this variable must therefore be taken into consideration in interpreting these results. Finally, our results are consistent with the possibility that the appearance of increased numbers of macrophages in the lower respiratory tract induced by cigarette smoking contributes to the lower incidence of pulmonary sarcoidosis in smokers.

We wish to thank Martine Grandsaigne, Paule Loiseau, and Françoise Mazin for their excellent technical assistance and Fabienne Miklovic for editorial assistance. The work was supported in part by a grant from the Comite National contre les Maladies Respiratoires et la Tuberculose (87G1).

\section{References}

1 Crystal RG, Bitterman PB, Rennard SI, Hance AJ, Keogh BA. Interstitial lung diseases of unknown cause. Disorders characterised by chronic inflammation of the lower respiratory tract. $N$ Engl J Med 1984;310:154-65, 235-44.

2 Rosen Y, Athaniades TJ, Moon S, Lyons HA. Non granulomatous interstitial pneumonitis in sarcoidosis. Chest 1978;74:122-5.

3 Hunninghake GW, Gadek JE, Kawanami O, Ferrans VJ, Crystal RG. Inflammatory and immune processes in the human lung in health and disease: evaluation by bronchoalveolar lavage. Am J Pathol 1979;97:149-206.

4 Reynolds HY. Bronchoalveolar lavage. Am Rev Respir Dis 1987;135:250-63.

5 Comstock GW, Keltz H, Senser DJ. Clay eating and sarcoidosis: a controlled study in the state of Georgia.
Am Rev Respir Dis 1961;84:130-4.

6 Terris M, Chaves AD. An epidemiologic study of sarcoidosis. Am Rev Respir Dis 1966;94:50-5.

7 Harf R, Perrin-Fayolle M. Sarcoidosis and smoking. In: Duric B, ed. Proceedings of the third European conference on sarcoidosis and other granulomatous diseases. Novi Sad: Sremka Kamenica, 1982:167-74.

8 Bresnitz EA, Strom BL. Epidemiology of sarcoidosis. Epidemiol Rev 1983;5:124-56.

9 Hance AJ, Basset F, Saumon G, et al. Smoking and interstitial lung disease. Ann NY Acad Sci 1986; 466:643-56.

10 Harf A, Ethevenaux C, Gleize J, Perrin-Fayolle M, Guerin JC, Ollagnier C. Reduced prevalence of smokers in sarcoidosis: results of a case-control study. Ann N Y Acad Sci 1986;465:625-31.

11 Douglas JG, Middleton WG, Gaddie J, et al. Sarcoidosis: a disorder commoner in non-smokers? Thorax 1986;41:787-91.

12 Valeyre D, Saumon G, Bladier D, et al. The relationship between noninvasive explorations in pulmonary sarcoidosis of recent origin, as shown in bronchoalveolar lavage, serum and pulmonary function tests. Am Rev Respir Dis 1982;126:41-5.

13 Valeyre D, Hance A, Soler P, et al. Sequence of cellular abnormalities in sarcoid alveolitis [abstract]. Am Rev Respir Dis 1985;131:A19.

14 Comité Français d'Education pour la Santé. Les français et le tabac. Tabac et Santé. 1983;52:10-3.

15 Smiejan JM, Cosnes J, Chollet-Martin S, et al. Sarcoidlike lymphocytosis of the lower respiratory tract in patients with active Crohn's disease. Ann Intern Med 1986;104:17-21.

16 Pré J, Bladier D. A rapid and sensitive spectrophotometric method for routine determination of serum angiotensin converting enzyme activity. ICRS Med Sci 1983;11:220-1.

17 Ogilvie CM, Forster RE, Blakemore WS, Morton JW. A standardized breath holding technique for the clinical measurement of the diffusing capacity of the lung for carbon monoxide. J Clin Invest 1957;36:1-17.

18 Quanjer PH. Standardized lung function testing. Ed. Bull Eur Physiopathol Respir 1983 (suppl) 5:191-5.

19 Georges R, Saumon G, Loiseau A. The relationship of age to pulmonary membrane conductance and capillary blood volume. Am Rev Respir Dis 1978;117:1069-78.

20 Line BR, Hunninghake GW, Keogh BA, Jones AE, Johnston GS, Crystal RG. Gallium 67 scanning to stage the alveolitis of sarcoidosis: correlation with clinical studies, pulmonary function studies and bronchoalveolar lavage. Am Rev Respir Dis 1981; 123:440-6.

21 Huchon GJ, Berrisoul F, Barritault LG, et al. Comparison of bronchoalveolar lavage and Gallium 67 lung scanning to assess the activity of pulmonary sarcoidosis. In: Chrétien J, Marsac J, Saltiel JC, eds. Sarcoidosis. Paris: Pergamon Press, 1983:440-5.

22 Siltzbach LE, James DG, Neville E, et al. Course and prognosis of sarcoidosis around the world. Am J Med 1974;57:847-52.

3 Warren CPW. Extrinsic allergic alveolitis: a disease 
commoner in nonsmokers. Thorax 1977;32:567-9.

24 Bresnitz EA, Stolley PD, Israel HL, Soper K. Possible risk factors for sarcoidosis. Ann NY Acad Sci 1986;465:632-42.

25 Dutton RE, Renzi PM, Lopez-Majano V, Renzi GD. Airway function in sarcoidosis: smokers versus non smokers. Respiration 1982;43:164-73.

26 Staton GW Jr, Gilman MJ, Pine JR, Fajman WA, Check IJ. Comparison of clinical parameters, bronchoalveolar lavage, gallium-67 lung uptake, and serum angiotensin converting enzyme in assessing the activity in sarcoidosis. Sarcoidosis 1986;3:10-8.

27 Mordelet-Dambrine MS, Stanislas-Leguern GM, Huchon GJ, Baumann FC, Marsac JH, Chrétien J. Elevation of the bronchoalveolar concentration of angiotensin I converting enzyme in sarcoidosis. Am Rev Respir Dis 1982;126:472-5.

28 Hinman LM, Stevens C, Matthay RA, Gee JBL. Angiotensin convertase activities in human alveolar macrophages: effects of cigarette smoking and sarcoidosis. Science 1979;205:202-3.

29 Line BR, Hunninghake GW, Keogh BA, Crystal RG. Gallium-67 scanning as an indicator of the activity of sarcoidosis. In: Fanburg BL, ed. Sarcoidosis and other granulomatous disease of the lung. New York: Marcel Dekker, 1983;287-322.

30 Bisson G, Drapeau G, Lamoureux G, Cantin A, RolaPleszczynski M, Bégin R. Computer-based quantitative analysis of gallium-67 uptake in normal and diseased lungs. Chest 1983;84:513-7.

31 Grönhagen-Riska C. Angiotensin-converting enzyme I. Activity and correlation with serum lysozyme in sarcoidosis, other chest or lymph node diseases and healthy persons. Scand J Respir Dis 1979;69:83-93.

32 Lawrence EC, Fox TB, Teague RB, Bloom K, Wilson RK. Cigarette smoking and bronchoalveolar $\mathrm{T}$ cell populations in sarcoidosis. Ann NY Acad Sci
Valeyre, Soler, Clerici, Pré, Battesti, Georges, Hance 1986;465:657-64.

33 Dauber JH, Rossman MD, Daniele RP. Bronchoalveolar lavage cell populations in acute sarcoidosis: observations in smoking and nonsmoking patients. $J$ Lab Clin Med 1979;94:862-71.

34 Yeager H, Williams MC, Beckman TC, Beamon BL, Hawley RJ. Sarcoidosis: analysis of cells obtained by lavage. Am Rev Respir Dis 1977;116:951-4.

35 Thomas PP, Hunninghake GW. Current concepts of the pathogenesis of sarcoidosis. Am Rev Respir Dis 1987; 135:747-60.

36 Liu MC, Proud D, Schleimer RP, Plaut M. Human lung macrophages enhance and inhibit lymphocyte proliferation. J Immunol 1984;132:2895-903.

37 Ettensohn DB, Lalor PA, Roberts NJ Jr. Human alveolar macrophage regulation of lymphocyte proliferation. Am Rev Respir Dis 1986;133:1091-6.

38 Rich EA, Tweardy DJ, Fujiwara H, Ellner JJ. Spectrum of immunoregulatory functions and properties of human alveolar macrophages. Am Rev Respir Dis 1987;136:258-65.

39 Holt PG. Immune and inflammatory function in cigarette smokers. Thorax 1987;42:241-9.

40 Daniele RP, Dauber JH, Altose MD, Rolands DT, Gorenberg DJ. Lymphocyte studies in asymptomatic cigarette smokers. Am Rev Respir Dis 1977;116: 997-1005.

41 deShazo RD, Banks DE, Diem JE, et al. Bronchoalveolar lavage cell-lymphocyte interactions in normal nonsmokers and smokers. Analysis with a novel system. Am Rev Respir Dis 1983;127:545-8.

42 Hance AJ, Douches S, Winchester RJ, Ferrans VJ, Crystal RG. Characterization of mononuclear phagocyte subpopulations in the human lung by using monoclonal antibodies: changes in alveolar macrophage phenotype associated with pulmonary sarcoidosis. J Immunol 1985;134:284-92. 